DOI 10.22363/2313-1683-2020-17-4-604-623

UDC 159.923.2

Research article

\title{
Posttraumatic Growth in Cambodia: A Mixed Methods Study
}

\author{
Julie Badaracco', Skultip Sirikantraporn ${ }^{2}$, Grant J. Rich ${ }^{3}$, \\ Julii Green ${ }^{1}$, Matthew C. Porter ${ }^{1}$
}

\author{
${ }^{1}$ Alliant International University \\ 1000 S Fremont Ave, bldg A7, Alhambra, CA 91803, United States of America \\ ${ }^{2}$ Fulbright University Vietnam \\ Floor 2, Crescent Plaza, 105 Ton Dat Tien, Tan Phu Ward, District 7, \\ Ho Chi Minh City, Socialist Republic of Vietnam \\ ${ }^{3}$ Walden University
}

100 Washington Ave South, suite 900, Minneapolis, MN 55401, United States of America

\begin{abstract}
The majority of psychological research has focused heavily on the negative outcomes of trauma and tends to ignore the positive outcomes of experiencing traumatic events. Posttraumatic growth (PTG) is a concept that stems from positive psychology and was originally developed by R.G. Tedeschi and L.G. Calhoun (2004). PTG is the process of growth after trauma and has been divided into five domains: greater appreciation for life, more intimate relationships, personal strength, recognition of new possibilities, and spiritual development. This mixed methods study utilizes archival data collected in 2015-2016 at the American University of Phnom Penh to examine the experience of growth after trauma that 70 Cambodian participants faced from a quantitative and qualitative perspective. Quantitative analysis determined that the Adult Resilience Measure (ARM) and the Posttraumatic Growth Inventory (PTGI) were considered internally reliable and valid measures when used with Cambodians. It was determined that the number of traumatic events one experiences does not influence one's ability to experience PTG or resiliency and the concepts of PTG and resiliency are correlated. The qualitative analysis utilized grounded theory to develop a theory of PTG within Cambodia. These results indicated that Cambodians experience PTG in four core categories including: personal strength, relational strength, avenues of growth and religion/spirituality. The quantitative and qualitative results illustrate that Cambodians experience PTG in a similar manner when compared to the original PTG theory. However, there are cultural nuances that must be taken into account when exploring PTG within the Cambodian population.
\end{abstract}

Key words: Cambodia, culture, cross-cultural, grounded theory, positive psychology, posttraumatic growth, resilience, Southeast Asia, trauma, mixed methods

\section{Introduction}

Psychology has adopted a disease-based model, meaning that researchers and clinicians tend to focus on the aliments of mankind rather than looking at the strengths and virtues of human beings. There is not enough attention given to

(C) Badaracco J., Sirikantraporn S., Rich G.J., Green J., Porter M.C., 2020

(c) (-) This work is licensed under a Creative Commons Attribution 4.0 International License https://creativecommons.org/licenses/by/4.0/ 
the importance of understanding that human beings are more than their shortcomings and illnesses, making it essential for clinicians and researchers to understand and learn how to foster feelings of contentment and happiness in their clients and participants as these are feelings that all human beings will experience (Zoellner, Maercker, 2006). There are certainly benefits in studying and understanding psychopathology and the impact of negative experiences of individuals, such as trauma, and is essential in assisting individuals to become their best selves. This is where the field of positive psychology interacts with the disease model of psychology, and it is one way to facilitate this growth for individuals seeking help (Seligman, 2011; Seligman, Csikszentmihalyi, 2000).

There has been a plethora of research examining the negative impact of trauma such as posttraumatic stress disorder (PTSD). PTSD is a debilitating psychological disorder that is characterized by intrusive symptoms, avoidance, and hypervigilance (American Psychiatric Association, 2013; Breslau et al., 1997; Hinton et al., 2005; Kessler, 2000; Nemeroff et al., 2006). Many individuals who have experienced, witnessed, seen or heard about one or more traumatic events may develop PTSD or related symptoms (Anda et al., 2006; American Psychiatric Association, 2013; Green, 1990; Green et al., 2000). Much of the early trauma research focused specifically on trauma stemming from armed combat and there continues to be a common belief that PTSD is a psychological disorder exclusively for individuals who have experienced armed combat (Nemeroff et al., 2006). This is a false belief as there are many other situations in which an individual can experience trauma including: physical, emotional, sexual and verbal abuse, sexual assault, natural disasters, unsafe environmental conditions, disease, and the death of a loved one (Bracken, 2002; Green, 1990).

It is important to note that trauma is experienced and understood in a variety of different ways depending on one's cultural background (Bracken, 2002; Cohen, 2009; Southwick et al., 2014; Ungar, 2008, 2013). The Diagnostic and Statistical Manual ( $5^{\text {th }}$ edition) is used to diagnose PTSD in western societies and captures the three main markers associated with psychological distress following a trauma including: intrusive symptoms, avoidance, and hyperarousal. These makers are seen as universal markers of psychological distress, although there are cultural differences that need to be accounted for. One of the first cultural differences is memory. It is fairly common for individuals to forget certain details of the trauma and there tends to be a difference in memory retention amongst individuals living in individualistic and collectivistic cultures (Bremner, 1998; Oyserman et al., 2002). Jobson and O'Kearney (2006) found that traumatic memories tend to be more autonomous experiences regardless of one's cultural orientation. Therefore, it may be difficult for individuals in a collectivistic culture to remember all of the details of the trauma they have experienced. Another cultural implication with psychological distress after a trauma is somatization, which occurs when an individual's psychological distress is manifested through physical symptoms such as headaches, chronic pain, and sleep disturbances. It is fairly common for individuals, especially from collectivistic cultures, to manifest their posttraumatic reactions through physical symptoms because of the social acceptability of exhibiting physical symptoms within their culture (Perry et al., 2007). 
Culture plays a role in how one experiences psychological distress after a traumatic event, and also impacts an individual's journey through healing, which varies widely based on the individual, cultural, socioeconomic, and environmental settings (Bonanno, 2004; Southwick et al., 2014; Ungar, 2008, 2013). Although, it is natural and normal to experience psychological distress, according to Victor Frankl (1970) human beings tend to be motivated by what he called "will to meaning". This concept outlines the idea that human beings are motivated and attempt to create meaning out of their lived experiences, even when those experiences are negative. Since Frankl (1970) there have been other developments in the field of psychology that focus on resilience and making meaning out of life. This study focuses on the process of growth after trauma, which is called posttraumatic growth (PTG) and was coined by Tedeschi and Calhoun (2004). PTG is the positive psychological change experienced as a result of adversity to rise to a higher level of functioning. During this process individuals undergo significant life-changing psychological shifts in thinking and ways of relating to the world that contribute to a personal process of change and making meaning of life (Tedeschi, Calhoun, 2004). Five domains exist within the PTG framework including: a greater appreciation for life and changed sense of priorities, more intimate relationships, a greater sense of personal strength, recognition of new possibilities in one's life, and spiritual development (Tedeschi, Calhoun, 2004). PTG may seem like an ideal solution to trauma, but this does not mean that everyone is able to achieve it. Simply because an individual achieves PTG does not mean that they will be symptom-free or that they will be able to return to their pre-trauma state (Tedeschi, Calhoun, 2004).

\section{Understanding the Cambodian Population}

The concept of PTG was developed in the West and has been found to be a fairly flexible concept, however it is important to understand how this concept relates to individuals in different cultural contexts and in individuals who have experienced different forms of trauma (Cohen, 2009; Flores, Ezemenari, 2003; Tedeschi, Calhoun, 2004). The Cambodian genocide is one of the least studied genocides to date and there has been comparatively little research by psychologists on this horrendous event on the Cambodian people (Chandler, 2007; Hinton, 2004; Kierman, 2008). Cambodia has a history marked by war and corrupt governments, with the Cambodian genocide being the most horrific period of human rights violations in the country's history. Prior to the start of the genocide in 1975, the country endured a civil war where the Pol Pot Regime came into power after a coup d'état (Chandler, 2007; Hinton, 2004; Van de Put, Eisenbruch, 2002). The Pol Pot Regime desired to return to the socialist agrarian society in which the regime believed Cambodia had been founded (Coe, 2005). 1975-1979 marked a period where intellectuals, monks, diplomats and any individuals in powerful positions were murdered. Cambodians living in urban areas were relocated to the countryside in an attempt to return to a traditional lifestyle, relying solely on agriculture. People were forced to work in the rice fields and were often starved to death. Children were trained to spy on their parents and notify officials if they caught their parents saying anything against the regime. People were interrogated and tortured to obtain background information regarding themselves and their community in an attempt to eradicate the intellectuals of the community (Van de Put, 
Eisenbruch, 2002). The Cambodian culture that existed was destroyed when the majority of the Buddhist temples were destroyed and monks were executed. Approximately two million people or $25 \%$ of the population were killed during these four years of genocide (Van de Put, Eisenbruch, 2002). The only chance of survival was escaping into Thailand or Vietnam, where it was likely that they would face persecution due to tense political relations as well as trauma during on their way to the refugee camps.

Forty-one years later, the Cambodian population continues to suffer from the adverse effects of the horrific tragedies they survived. The country continues to rebuild the society and communities that were destroyed, but the current political and human rights status is dire. These human rights concerns include large garment and textile companies evicting individuals from their property without warning or permission and the creation of facilities labeled "Drug Treatment Centers", which are being used as detention centers for "undesirable people" including individuals who are homeless, using drugs, sex workers, street children and the mentally ill (Amnesty International, 2016; Amon et al., 2013; Human Rights Watch, 2017). Cambodia has experienced significant economic growth over the past decades, which is difficult to maintain due to the corruption within the Cambodian government (Human Rights Watch, 2017; World Bank, 2017). There has been comparatively little research examining the overall wellbeing of the Cambodian people and whether they have experienced growth despite the adversities they faced in the form of genocide, government corruption and the continued violation of human rights.

The purpose of this study is to generate a theoretical model that explains the way PTG is experienced within the Cambodian population. Specifically, this study aims to examine the experience of PTG and resiliency within the Cambodian population and create a preliminary theory regarding the domains of PTG that are relevant to Cambodian individuals.

\section{Methods}

This study utilized archival data that was collected between 2015-2016 by Skultip Sirikantraporn and Grant Rich and was a collaboration between Alliant International University (AIU), and Grant Rich and colleagues at the American University of Phnom Penh (AUPP). The data were collected in Cambodia and IRB approval was obtained from both AIU and AUPP on April 2, 2015. A mixed methods research design was utilized as this allows for the opportunity to capture the true experience of the participants who have endured some form of trauma, and is one of the first studies of its kind. This study illuminates some of the processes that these participants experience after trauma and how they were able to process trauma and create a meaningful life.

\section{Procedures}

This study involved 70 male and female volunteers, over the age of 18 participating in the quantitative part of the study. All participants read and spoke Khmer and/or English fluently and those participating in the qualitative interview portion had reported experiencing at least one traumatic event. The study was conducted in Khmer or English depending on the participants' preferred language 
and all research assistants were bilingual in Khmer and English. Individuals were excluded from the study if they were younger than 18 years of age, did not read or fluently speak Khmer or English, and reported having active suicidal ideation in the last three months. Of the 70 participants, there were 9 who participated in the interview portion, which included a semi-structured interview guide focused on the domains of PTG. The quantitative portion of the study asked the participants to complete the following questionnaires: a demographic form, Posttraumatic Growth Inventory, Adult Resilience Measure, and the Life Event Checklist.

\section{Participants}

Participants were recruited by the posting of ads at universities, hospitals, libraries and community centers in Phnom Penh, the capital of Cambodia. The researchers had permission from AUPP to visit classrooms, explain the study and leave flyers with students. Interested students were asked to contact the researcher and screened for eligibility. Attempts were made to recruit Cambodian adult participants of all ages (over 18) and genders. This study was conducted with a population that has endured much human suffering, therefore it was important to ensure that the participants were protected. There were minimal risks associated with this study, however it is possible that participants may have experienced distress when answering questions related to trauma. The researchers minimized risk by verifying that the participants understood the purpose of the study, and that they had the option to skip any questions and/or stop their participation at any time without repercussion. Every participant was offered mental health resources, including free services in Phnom Penh and was encouraged to seek these services if needed.

\section{Measures}

The measures below have all been front and back translated into Khmer to ensure exact translation and that the meaning was not lost during the translation process (Magnusson, Marecek, 2015).

Adult Resilience Measure (ARM). The Adult Resilience Measure has a total of 28 items and utilizes a 5-point Likert scale. The ARM measures three components of resilience including the individual's characteristics of resilience, relational resources with others and the contextual resources that facilitate a sense of belonging (Liebenberg et al., 2012). The ARM has been found to have adequate psychometric properties, is reliable and a valid self-report measure (Liebenberg et al., 2012).

Demographics form. The demographic form was developed by Skultip Sirikantraporn and Grant Rich, and consists of eight questions regarding the following demographic data: age, gender, income, religious preferences, and occupation.

Life Event Checklist (LEC). The Life Event Checklist consists of 17 items and utilizes a 5-point Likert scale. The measure requires participants to disclose what types of traumatic events they have experienced and in what capacity they were exposed to the trauma. The LEC is one of the only measures that examine the types of potentially traumatic events that one may experience, and is used widely in PTSD research (Gray et al., 2004). It was found to have generally adequate psychometric properties and that individuals who experienced more potentially traumatic events were more likely to meet diagnostic criteria for PTSD (Gray et al., 2004). 
Posttraumatic Growth Inventory (PTGI). The Posttraumatic Growth Inventory consists of 21 items and utilizes a 6-point Likert scale. The PTGI assesses the positive outcomes that may occur after one experience's a traumatic event, and is the most commonly used assessment tools for PTG (Zoellner, Maercker, 2006). This measure is based on the five domains of PTG including: new possibilities, relating to others, personal strength, spiritual change, and appreciation of life (Tedeschi, Calhoun, 1996, 2004). The PTGI is shown to have a very high internal consistency (Cranach's $\alpha=0.94$ ) and acceptable test-retest reliability ( $r=0.71)$ (Tedeschi, Calhoun, 1996). The PTGI has been shown to possess adequate psychometric properties and is a valid and standardized self-report measure for PTG (Tedeschi, Calhoun, 1996; Zoellner, Maercker, 2006).

Semi-structured interview. Skultip Sirikantraporn, Grant Rich and their research assistants developed the interview guide. The semi-structured interview included 20 open-ended questions regarding the participants' experience with trauma, how they processed the trauma and make meaning of their life after a traumatic event by accounting the concepts of growth, resilience, optimism, hardiness, and sense of coherence. The interviews took approximately one hour to one and a half hours to complete. The questions incorporated the participants' thoughts on how they had changed in the five domains of PTG including the relationship with oneself, relationship with others, spirituality, personal growth, and meaning in life. All interviews were conducted in Khmer and English depending on participant preference.

\section{Provision of Trustworthiness}

Several strategies were utilized to increase the trustworthiness of the study findings. The first strategy was peer scrutiny of the research project, where three coders independently coded the data. The coders compared categories and themes that emerged in the data and resolved any discrepancies there may be until there was a final agreement upon the categories and themes that emerged. The second strategy was an audit trail and journaling among the researchers, regarding their thoughts of the content of the data including any personal biases that may impact the researchers' ability to be neutral coder. This was an attempt to minimize the influence of the researchers' biases on the research procedures and findings by increasing their reflexivity and progressive subjectivity (Lincoln, Guba, 1985).

\section{Data Analysis}

A mixed methods research design was utilized as this provides a more comprehensive understanding of the participants' true experience of growth after trauma. The quantitative portion of this study utilized SPSS Statistics 25, a statistical analysis program, to complete the quantitative data analysis. Descriptive statistics including means and frequencies were used to describe the characteristics of the participants. Cronbach's $\alpha$ was used to determine the internal reliability of the ARM and PTGI within the Cambodian population. Pearson's correlations were conducted to examine the relationship between the number of traumatic life events and one's perception of posttraumatic growth and resiliency, as well as the correlation between the concepts of posttraumatic growth and resilience. Finally, a linear regression was used to determine whether resilience is a possible predicting factor of posttraumatic growth. 
The qualitative portion of this study utilized grounded theory due to its flexible nature and ability to be used accurately with a wide variety of research topics (Strauss, Corbin, 1994). Grounded theory is a general methodology used for developing theory grounded in the data, which is systematically gathered and analyzed (Corbin, Strauss, 1990; Strauss, Corbin, 1994). To create a grounded theory there are three basic methods of coding including open, axial and selective coding (Corbin, Strauss, 1990; Strauss, Corbin, 1994). Open coding is the first process in which the data is broken down analytically. Any events, actions and interactions that occur during the data collection phase are compared for similarities and differences, and are then grouped to form categories (Corbin, Strauss, 1990; Strauss, Corbin, 1994). Open coding was conducted using inVivo12, qualitative research analysis software, designed for more ease when completing open coding. Axial coding is conducted and requires that the categories created in the open coding phase be further refined. Researchers attempt to relate categories and subcategories to one another and test their relationship against the data that has been collected. This is where hypothetical relationships can be proposed, however they should be considered provisional until they are verified repeatedly against the data (Corbin, Strauss, 1990; Strauss, Corbin, 1994). Selective coding is the phase in which all of the formed categories are unified to create a core category, also known as the central phenomenon of the study. The selective coding phase is when the categories that require further explanation are completed with descriptive details (Corbin, Strauss, 1990; Strauss, Corbin, 1994).

\section{Results}

\section{Quantitative Data Analysis}

A total of 70 individuals completed the quantitative measures, however three individuals did not meet the inclusion criteria due to being under the age of 18, making a new total of 67 participants. See Table for the demographics of participants.

Demographics

\begin{tabular}{cc|cc}
\hline Characteristics & Total $(\boldsymbol{n})$ & Characteristics & Total (n) \\
\hline Age & & Education & 2 \\
$18-20$ & 38 & Elementary school & 46 \\
$21-25$ & 22 & Completed high school & 19 \\
$26-30$ & 4 & Obtained higher education & \\
$31-35$ & 1 & & 12 \\
$36-40$ & 1 & Employment & 1 \\
Sex & & Employed for wages & 1 \\
Female & 29 & Out of work for more than 1 year & 1 \\
Male & 37 & Out of work for less than 1 year & 1 \\
Other & 1 & Homemaker & Student \\
Marital status & & Decline to answer & \\
Single & 61 & & \\
Married & 3 & Religion & 1 \\
Decline to answer & 3 & Buddhism & 1 \\
Income & & Christianity & Other \\
High & 6 & Decline to answer & \\
Moderate & 48 & & \\
Low & 11 & &
\end{tabular}


The average age for participants was $21.06(\mathrm{SD}=3.87)$, with $55 \%$ of participants being male $(n=37)$ and $43 \%$ were female $(n=29)$. $91 \%$ of participants identified as single $(n=61)$, with $4 \%$ identifying as married $(n=3) .71 \%$ of participants identified with being in the moderate range for income $(n=48) .69 \%$ of participants identified as having completed high school $(n=46)$ and $76 \%$ reported being students $(n=51), 94 \%$ identified as Buddhist $(n=63)$.

Preliminary analyses. A series of preliminary analyses were conducted to verify that the analyses for the data would be plausible. A Pearson's correlation determined that there was a strong positive correlation between age and PTGI ( $r=0.84, n=67, p=0.025)$ and a significant negative correlation between age and ARM scores $(r=0.174, n=67, p=-0.168)$. An independent t-test was conducted to compare sex and scores on the PTGI and ARM, and determined that there was not a significant difference in the scores for PTGI $(\mathrm{M}=87.85, \mathrm{SD}=20.93)$ and ARM $(\mathrm{M}=101.96, \mathrm{SD}=19.17) ; t(64)=-0.03, p=0.97$. A chi-square determined that there were no associations between income and scores on the PTGI and ARM, $\chi^{2}(114)=123.14, p=0.26$. These results illustrate that preexisting characteristics will not hinder one's ability to experience PTG or resiliency.

Hypothesis analysis. After a Cronbach's $\alpha$ internal reliability test was conducted it was found that the ARM and PTGI have a high level of internal reliability $(\alpha=0.89)$ when used with this population. Additionally, a Pearson's correlation was conducted and determined that there was no correlation between the number of traumatic life events and perception of PTGI ( $r=0.04, n=67, p=0.76)$. It was also indicated that the relationship between the number of traumatic life events and resilience was not statistically significant $(r=0.03, n=67, p=0.79)$. Another Pearson's correlation analysis determined that there was a statistically significant correlation between posttraumatic growth and resiliency $(r=0.58$, $n=67, p=0.00)$. Finally, a simple linear regression was calculated to predict posttraumatic growth based on an individual's experience of resiliency, and found a significant regression equation $(F(1,65)=32.75, p<0.00)$, with an $R^{2}$ of 0.33 . Resiliency is a predictor of a participant's perception of posttraumatic growth.

\section{Qualitative Data Analysis}

The qualitative data determined that there were four core categories including: personal growth, relational growth, spiritual growth and avenues of growth. These categories appear to align with the original posttraumatic growth theory developed by Tedeschi \& Calhoun (2004). Each category will be further explored and outlined below. See Figure for a visual graphic of the core categories and themes.

Core categories. Personal growth. During the qualitative analysis it was apparent that personal growth after a traumatic event was essential for the interviewees. The sub-themes that contributed to this core category include: (a) acceptance, (b) self-efficacy, and (c) self-actualization. Many interviewees expressed the necessity of acceptance of the traumatic event and how this led them to view themselves in a different light. This is evident by this quote (P10, Male): "You know, it's been a long time, so I kind of made peace with it." Self-efficacy emerged as a sub-theme as the interviewees experienced an increase in self-confidence and felt they could succeed in various tasks regardless of how difficult they might 
perceive them. This was evident by Participant 1 (Female) who stated, "It give me strength, it makes me feel that... I can do everything as long as I want to do it." For many of the participants, the traumatic event allowed them to learn more about themselves including their perception of their strengths and weaknesses. The final sub-theme is self-actualization, the belief that an individual has the capacity to thrive and learn from their trauma to become a better person. Participant 8 (Female) stated: "I want, in the future, I want to become rich and have a good family. I hope that my family will be healthy and wealthy. So it's not only about having the family or enough money, but it's about the self-actualization, fulfillment." This quote captures the idea that participants come to an understandding that they not only have the capacity to thrive, but to become a better person independent of their family. Personal growth was a major area of growth for the interviewees and illustrates the ways they grew independently after their experience of trauma.

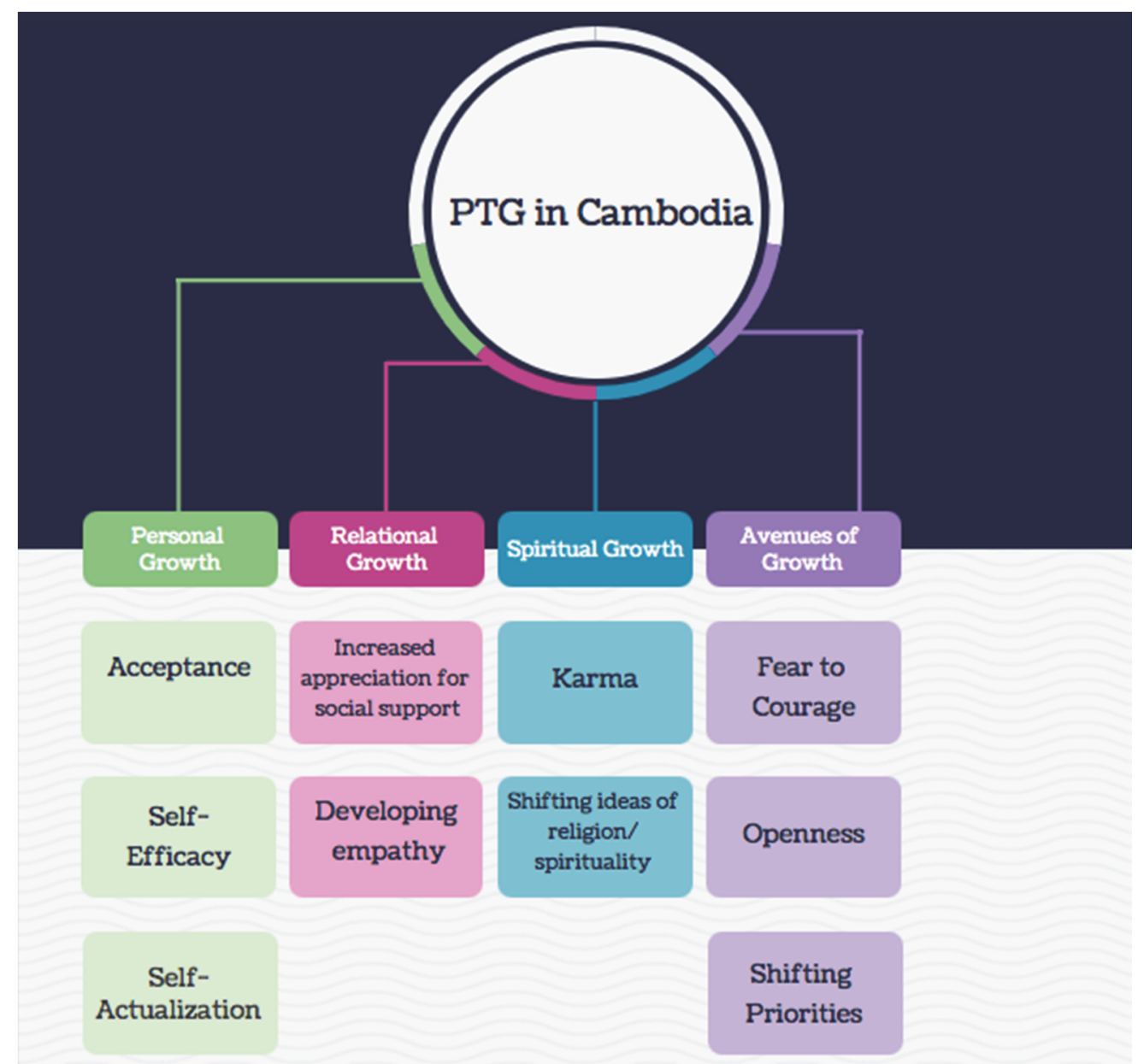

Figure. Mind map of the categories and sub-themes illustrated through the qualitative analysis of data

Relational growth. Another category that emerged from the interviews was relational growth. The sub-themes included in this category are the following: (a) increased appreciation for social support, and (b) developing empathy. One of 
the most prominent sub-themes was an increased appreciation for social support, as every interviewee discussed the importance of social support. Participant 6 (Female) highlights the importance of having social support after a traumatic event through this quote: "Sometimes I got tired in life, or because I experienced something bad, what I usually do is sit down, relax, have some sleep and then think back and try to find some factor that encourages me, especially my family; I just recover back from everything, and also people around me also make me feel better."

One of the primary forms of social support discussed in the interviews as being the most appreciated was family. Participant 1 (Female) stated, "I always think about my parents, like if I'm not gonna get out of it or something like that. Or if I'm going to hurt myself then I'm just going to put every people that love me in pain." Another interesting and unexpected sub-theme that emerged was the development of empathy. Many interviewees discussed how prior to the traumatic event they struggled to see other's perspectives. However, after experiencing a trauma many interviewees developed a deeper sense of empathy and understanding for other people's struggles. Participant 3 (Female) stated, "I've become a lot more empathetic about everything," and this is an important theme as many interviewees reported that because of their newfound empathy they were better able to connect with others and form meaningful relationships. This category illustrates the importance of social support as well as a shift in relating to others after a traumatic life event.

Spiritual growth. Spiritual growth was another core category that appeared to be an essential part of each of interviewees journey to PTG. The sub-themes that encompass this core category are (a) karma, and (b) shifting ideas of religion/ spirituality. Karma can be defined as "the balance of good and negative deeds from this or a previous life or 'fate' " (Schnuert et al., 2012). Although there were mixed views on the role of religion and spirituality after trauma, many interviewees discussed the role that karma plays in their daily life, as noted by Participant 8 (Female) who stated, "I think after the fire caught the other shops and we recovered from it, my mother and me, we prayed to $[\mathrm{xx}]$ and I mean, we tried to do something good. We believe in it." It is of interest that not all participants labeled the experience of karma with this terminology, but explained the belief. Additionally, there seemed to be somewhat of a shift in the ideas of religion and spirituality. There were mixed perceptions on this topic and it was mentioned that the majority of the interviewees felt that they had either maintained or became more religious/spiritual. Spiritual growth appeared to be impacted by the interviewee's traumatic event and had meaning as to how each individual understood themselves and their life.

Avenues of Growth. The final core category that emerged from the qualitative analysis was that of avenues of growth. Although each interviewee experienced growth differently there were three sub-themes including: (a) fear to courage, (b) openness, and (c) shifting priorities. One means of achieving growth and success was the experience of what it was like to move from experiencing fear to an increased sense of courage. Several interviewees stated that they had felt fear during the traumatic event, but learned how to be courageous in the face of adversity, and were able to move forward in life and become stronger individuals. Partici- 
pant 1 (Female) stated "I actually got more confident after the event, the fearful event", which was also echoed by Participant 4 (Male) statement of "I am able to pick myself up and start over, like not dwelling on some uh bad experience in the past that hinder me from achieving other thing that I want in life." The notion of being fearful was found to be a pivotal and necessary experience for interviewees to achieve growth. Additionally, the change in one's mindset after experiencing a trauma included feeling more open to new and different experiences compared to before. Participant 1 (Female) stated, "I see things differently, before... I used to be really closed minded about things but after that I actually see things more wide and clear." Another area of growth includes the shifting of priorities; many interviewees discussed how prior to the traumatic events they had been hyper focused on achieving personal success. However, after the traumatic event many noticed a shift in life priorities. "I change my future, my ambitions, my goals, after I encountered that situation" (P2, Male) truly encompasses the notion that everything changed in one's life after experiencing a trauma. Overall, the grounded theory analysis determined that Cambodian individuals developed a sense of personal strength and maturity that is evident in their own personal growth, enriched connections with others and their sense of spirituality as well as the ability to continue growing and finding meaning in life after hardships.

\section{Discussion}

To fully examine the results of the study it is important to understand the participants, as this will provide context for both the quantitative and qualitative results. The majority of the participants in the study, specifically in the quantitative portion of the study, were young, single males who were students, had moderate incomes and identified as Buddhist. This is a fairly specific population and may have differing views of the world compared to their older counterparts (Schnuert et al., 2012), which limits the generalizability of the study findings. Although the Khmer Rouge did not directly impact this specific population of Cambodians, they have experienced the effects of intergenerational trauma and continuous political difficulty throughout their lifetime (Amnesty International, 2016; Amon et al., 2013; Bar-On et al., 1998; Field et al., 2013; Human Rights Watch, 2015, 2017). Additionally, this population is privileged in some ways including their gender, financial and educational status, and may not be the most representative of the Cambodian population. However, studying their experiences of trauma, and PTG is essential, especially because the Cambodian population is typically not studied.

During the quantitative analysis the ARM and PTGI had to be translated accurately from English into Khmer and were found to be internally reliable measures in Khmer and English $(\alpha=0.89)$. The analysis determined that an individual is capable of experiencing resiliency and PTG after one or many traumatic events. Therefore, resilience and PTG should not be seen as a phenomenon that can only occur after a specific number of traumatic events. As the literature demonstrated there are differences in the experience of resiliency and PTG. Although, there is a strong positive relationship between resilience and PTG, which indicates that both are related and should not be thought of as exclusive experiences. Additionally, the notion that 
resiliency is a predictive factor of PTG has been confirmed within other populations including women with infertility problems (Yu et al., 2014), Chinese trauma survivors (Duan et al., 2015), survivors of motor vehicle accidents (Nishi et al., 2010) and survivors of the Yangzhou earthquake (Wu et al., 2015). This is an important finding as many Cambodians have experienced trauma and this could be incorporated into the clinical work being done with the Cambodian population (Schunert et al., 2012). This relationship has the ability to assist clinicians in determining what types of therapy would allow for the best facilitation of healing and growth.

The quantitative results indicate that the Cambodian population experiences PTG, which is an important finding as the cross-cultural literature on PTG is limited. By adding to the cross-cultural literature on PTG, it creates a deeper understanding of the phenomenon and ways this it is experienced by Cambodian individuals. These findings illustrate that Cambodians do experience PTG and resiliency, and that these concepts are relevant and related for Cambodians.

The qualitative analysis reveals that these Cambodian individuals developed a sense of personal strength and maturity that is evident in their own personal growth, enriched connections with others and their sense of spirituality as well as the ability to continue growing and finding meaning in life after hardships. Although these concepts differ somewhat from the original theory and domains of posttraumatic growth, there are striking similarities including the notion of new possibilities, relating to others, changed sense of priorities and spiritual change (Tedeschi, Calhoun, 2004). These categories illustrate that the notion of posttraumatic growth within this particular Cambodian population is similar to the experience of posttraumatic growth in westernized and individualistic cultures. It is possible that this theory may be accurate for the Cambodian population as a whole, however further studies are needed with a more diverse participants to confirm this theories generalizability.

\section{Conclusion}

\section{Clinical and Theoretical Implications}

Prior to this study, there had been no studies examining PTG in Cambodia and few studies on the cross-cultural relevance of PTG. This study has demonstrated that Cambodian individuals experience PTG in a fairly similar manner as Caucasian Americans and other Westernized individuals. This is important as this implies that many of the clinical interventions used with Americans and other Westernized individuals have the potential of being beneficial for this population. That being said, it is also apparent that for Cambodians interpersonal relationships are essential to foster growth after trauma.

As was previously mentioned Cambodians have experienced much human suffering and trauma at the hands of the Pol Pot Regime as well as the current political climate (Chan, 2015; Strangio, 2014; Van de Put, Eisenbruch, 2002). Marshall, Schell, Elliott, Berthold and Chun (2005) found that 99\% of Cambodian refugees experienced at least one traumatic event while living in Cambodia and $70 \%$ had been exposed to violence after resettling in the United States. These results have the potential to create a foundation for potentially effective mental health treatments for traumatized Cambodians. One potential clinical intervention that could assist Cambodians in the healing process would be allowing for individuals 
to disclose trauma stories and reconstruct them (Uy, Okubo, 2018). The trauma narrative enables individuals to promote self-healing and growth, but also facilitates the healing and growth of the Cambodian community (Uy, Okubo, 2018). These findings indicate that psychotherapy interventions such as Narrative Exposure Therapy (NET) may be beneficial for Cambodians as it is based on the creation and modification of narratives (Schaal et al., 2009). Additionally, it is essential that clinicians incorporate the spiritual and religious beliefs that are deeply engrained in Cambodian culture and society (Schaal et al., 2009; Uy, Okubo, 2018). The creation of effective mental health treatments for Cambodians and Cambodian Americans is essential, as this is a population that has suffered for many generations and could truly benefit from the creation of more effective mental health treatments.

Finally, this research adds to the cross-cultural literature on PTG. The majority of the studies in positive psychology and PTG focus on Caucasians. Therefore, it is essential that we continue to examine the experience of PTG among a variety of different countries and cultures, as it is possible that individuals experience growth after trauma differently. When there is more cross-cultural research in the field of PTG this will allow researchers and clinicians alike to better understand and serve these populations mental health needs. Having access to crosscultural research is necessary for the field of psychology to continue growing and staying relevant with an ever-growing population.

\section{Limitations}

One of the major limitations of this study is that it utilized archival data. Due to the limitations that are part of international research the diversity of the recruited participants was also limited. Many of the participants were young, male students, which is not considered a representative sample within Cambodia. Therefore, the results from this study should be utilized with caution. Additionally, the ARM and PTGI translated into Khmer have not had formal psychometric analyses completed and therefore cannot be fully determined as reliable and valid measures. However, as the quantitative results indicate these measures are internally reliable and valid measures in the preliminary psychometric analysis that were completed. Although it was not ideal that these measures were utilized, there are no existing measures in Khmer that have psychometric properties. Another limitation is the nature of qualitative research and grounded theory methodology, which attempts to develop new theory based on the in-depth experiences of a limited number of individuals who have a shared experience. However, due to the small number of individuals who are needed to complete the grounded theory analysis it is possible that saturation was not achieved and therefore the generalizability of these findings are limited.

\section{Future Research Directions}

Future research could include a variety of different elements including conducting studies to determine the psychometric properties of the ARM and PTGI in Khmer. It would also be appropriate to develop a version of the PTGI that can be used specifically with the Cambodian population. The development of a culturally specific PTGI would allow for the incorporation of a more culturally sensitive measure, as it would utilize the framework of PTG that is specific to Cambodians. 
Another future research idea would be to conduct the same study, but with a diverse group of participants (e.g., gender, age, religion, income) and in the form of a longitudinal study. Future research may also include conducting similar studies in different regions of the world such as the Middle East, Latin America, and Africa. Exploring the differences of posttraumatic growth and resiliency for individuals living in other parts of the world is vital to the growth of positive psychology as a whole.

\section{References}

American Psychiatric Association. (2013). Diagnostic and statistical manual of mental disorders $\left(5^{\text {th }}\right.$ ed.). Washington, DC, US: American Psychiatric Association.

Amnesty International. (2016). Cambodia 2016/2017. Retrieved July 11, 2017, from https:/www.amnesty.org/en/countries/asia-and-the-pacific/cambodia/report-cambodia/

Amon, J., Barriga, S.R., Sheppard, B., Robertson, P., Ross, J., \& Haas, D. (2013). "They treat us like animals": Mistreatment of drug users and "undesirables" in Cambodia's Drug Detention Centers. Human Rights Watch. Retrieved on July 12, 2017, from https://www.hrw.org/report/2013/12/08/they-treat-us-animals/mistreatment-drug-usersand-undesirables-cambodias-drug\#page

Anda, R.F., Felitti, V.J., Bremner, J.D., Walker, J.D., Whitfield, C., Perry, B.D., ...Giles, W.H. (2006). The enduring effects of abuse and related adverse experiences in childhood: A convergence of evidence from neurobiology and epidemiology. European Archives of Psychiatry Clinical Neuroscience, 256, 174-186. https://doi.org/10.1007/s00406-005-0624-4

Bar-On, D., Eland, J., Kleber, R.J., Krell, R., Moore, Y., Sagir, A. ... van Ijzendoorn, M.H. (1998). Multigenerational perspectives on coping with the Holocaust experience: An attachment perspective for understanding the developmental sequelae of trauma across generations. International Journal of Behavioral Development, 22, 315-338. https://doi.org/10.1080/016502598384397

Berntsen, D., \& Rubin, D.C. (2006). When trauma becomes a key to identity: Enhanced integration of trauma memories predicts posttraumatic stress disorder symptoms. Applied Cognitive Psychology, 21, 417-431. https://doi.org/10.1002/acp.1290

Bonanno, G.A. (2004). Loss, trauma, and human resilience: Have we underestimated the human capacity to thrive after extremely aversive events? American Psychologist, 59(1), 20-28.

Bracken, P. (2002). Trauma: Culture, meaning and philosophy. Whurr Publishers.

Bremner, J.D. (1998). Neuroimaging of posttraumatic stress. Psychiatric Annals, 28, 445-450.

Breslau, N., Davis, G.C., Andreski, P., Peterson, E.L., \& Schultz, L.R. (1997). Sex differences in posttraumatic stress disorder. Archives of General Psychiatry, 54, 1044-1048.

Chan, S. (2015). Cambodians in the United States: Refugees, immigrants, American ethnic minority. Oxford Research Encyclopedias. https://doi.org/10.1093/acrefore/9780199329175.013.317

Chandler, D. (2007). A history of Cambodia (4th ed.). Philadelphia, PA: Westview.

Coe, M.D. (2005). Angkor and the Khmer Civilization. New York, NY: Thames Hudson.

Cohen, A. B. (2009). Many forms of culture. American Psychologist, 64, 194-204.

Corbin, J., \& Strauss, A. (1990). Grounded theory research: Procedures, canons, and evaluative criteria. Qualitative Sociology, 13(1), 3-21.

Duan, W., Guo, P., \& Gan, P. (2015). Relationships among trait resilience, virtues, posttraumatic stress disorder and posttraumatic growth. PLoS ONE, 10(5). https://doi.org/10.1371/journal.pone.0125707

Field, N.P., Muong, S., \& Sochanvimean, V. (2013). Parental styles in the intergenerational transmission of trauma stemming from the Khmer Rouge regime in Cambodia. American Journal of Orthopsychiatry, 83, 483-494. https://doi.org/10.1111/ajop.12057

Flores, L.Y., \& Ezemenari, M.O. (2003). Positive psychological assessment in an increasingly diverse world. In S.J. Lopez, \& C.R. Snyder, Positive Psychological Assessment: 
A handbook of models and measures (pp. 41-54). Washington D.C., US: American Psychological Association. https://doi.org/10.1037/10612-003

Frankl, V.E. (1970). The will to meaning: Foundations and applications of logotherapy. New York, New York: Plume.

Gray, M.J., Litz, B.T, Hsu, J.L., \& Lombardo, T.W. (2004). Psychometric properties of the life events checklist. Assessment, 11(4), 330-341. doi: 10.1177/1073191104269954.

Green, B.L. (1990). Defining trauma: Terminology and generic stressor dimensions. Journal of Applied Social Psychology, 20, 1632-1642. https://doi.org/10.1111/j.15591816.1990.tb01498.x

Green, B.L., Goodman, L.A., Krupnick, J.L., Corcoran, C.B., Petty, R.M., Stockton, P., \& Stern, N.M. (2000). Outcomes of single versus multiple trauma exposure in a screening sample. Journal of Traumatic Stress, 13, 271-286. https://doi.org/10.1023/A:1007758711939

Hinton, A. (2004). Why did they kill?: Cambodia in the shadow of genocide. Berkeley, California: University of California Press.

Hinton, D.E., Chhean, D., Pich, V., Safren, S.A., Hofmann, S.G., \& Pollack, M.H. (2005). A randomized controlled trial of cognitive-behavioral therapy for Cambodian refugees with treatment-resistant PTSD and panic attacks: A cross-over design. Journal of Traumatic Stress, 18, 617-629. https://doi.org/10.1002/jts.20070

Human Rights Watch (2017). Cambodia Events of 2016. Retrieved from https://www.hrw.org/world-report/2017/country-chapters/cambodia

Human Rights Watch. (2015). World Report: Cambodia Events of 2014. Retrieved from https:/www.hrw.org/world-report/2015/country-chapters/cambodia

Jobson, L., \& O'Kearney, R. (2006). Cultural differences in autobiographical memory of trauma. Clinical Psychologist, 10, 89-98. https://doi.org/10.1080/13284200600939892

Kessler, R.C. (2000). Posttraumatic stress disorder: The burden to the individual and to society. Journal of Clinical Psychiatry, 61, 4-12.

Kierman, B. (2008). The Pol Pot Regime: Race, power, and genocide in Cambodia under the Khmer Rouge, 1975-1979 ( $3^{\text {rd }}$ ed.). New Haven, Connecticut: Yale University Press.

Liebenberg, L., Ungar, M., \& Van de Vijver, F. (2012). Validation of the child and youth resilience measure - 28 (CYRM-28) among Canadian youth. Research on Social Work Practice, 22, 219-226. https://doi.org/10/1177/1049731511428619

Lincoln, Y.S., \& Guba, E.G. (1985). Naturalistic inquiry (vol. 75). London, United Kingdom: Sage.

Magnusson, E., \& Marecek, J. (2015). Doing interview-based qualitative research: A learner's guide. Cambridge, United Kingdom: Cambridge University Press.

Marshall, G.N., Schell, T.L., Elliott, M.N., Berthold, S.M., \& Chun, C. (2005). Mental health of Cambodian refugees 2 decades after resettlement in the United States. JAMA, 294(5), 571-579. https://doi.org/10.1001/jama.294.5.571

Nemeroff, C.B., Bremner, J.D., Foa, E.B., Mayber, H.S., North, C.S., \& Stein, M.B. (2006). Posttraumatic stress disorder: A state-of-the-science review. Journal of Psychiatric Research, 40, 1-21. https://doi.org/10.1016/j.jpsychires.2005.07.005

Nishi, D., Matsuoka, Y., \& Kim, Y. (2010). Posttraumatic growth, posttraumatic stress disorder and resilience of motor vehicle accident survivors. Biopsychosocial Medicine, 4(7).

Oyserman, D., Coon, H.M., \& Kemmelmeier, M. (2002). Rethinking individualism and collectivism: Evaluation of theoretical assumptions and meta-analyses. Psychological Bulletin, 128, 3-72. https://doi.org/10.1037//0033-2909.128.1.3

Perry, C.T., Oum, P., \& Gray, S.H. (2007). The body remembers: Somatic symptoms in traumatized Khmer. Journal of the American Academy of Psychoanalysis \& Dynamic Psychiatry, 35, 77-84. https://doi.org/10.1521/jaap.2007.35.1.77

Schaal, S., Elbert, T., \& Neuner, F. (2009). Narrative exposure therapy versus interpersonal psychotherapy: A pilot randomized controlled trial with Rwandan genocide orphans. Psychotherapy and Psychosomatics, 78, 298-306. https://doi.org/10.1159/000229768

Schunert, T., Khann, S., Koa, S., Pot, C., Saupe, L.B., Lahar, C.J., ... Nhong, H. (2012). Cambodian Mental Health Survey. Department of Psychology, Royal University of Phnom Penh. 
Seligman, M. (2011). Flourish. New York City, New York: Free Press.

Seligman, M., \& Csikszentmihalyi, M. (2000). Positive psychology. American Psychologist, 55, 5-14. https://doi.org/10.1037//0003-066X.55.1.5

Southwick, S.M., Bonanno, G.A., Masten, A.S., Panter-Brick, C., \& Yehuda, R. (2014). Resilience definitions, theory, and challenges: Interdisciplinary perspectives. European Journal of Psychotraumatology, 5(1), 25338.

Strangio, S. (2014). Hun Sen's Cambodia. New Haven, Connecticut: Yale University Press.

Strauss, A., \& Corbin, J. (1994). Grounded theory methodology. Handbook of qualitative research, 17, 273-285.

Tedeschi, R.G., \& Calhoun, L.G. (1996). The posttraumatic growth inventory: Measuring the positive legacy of trauma. Journal of Traumatic Stress, 9, 455-471.

Tedeschi, R.G., \& Calhoun, L.G. (2004). Posttraumatic growth: Conceptual foundations and empirical evidence. Psychological Inquiry, 15, 1-18.

Ungar, M. (2008). Resilience across cultures. British Journal of Social Work, 38, 218-235.

Ungar, M. (2013). Resilience, trauma, context, and culture. Trauma, violence, \& abuse, 14(3), $255-266$.

Uy, K.K., \& Okubo, Y. (2018). Reassembling a shattered life: A study of posttraumatic growth in displaced Cambodian community leaders. Asian American Journal of Psychology, 9(1), 47-61. https://doi.org/10.1037/aap0000111

Van de Put, W.A.C.M., \& Eisenbruch, I.M. (2002). The Cambodian Experience. In J.D. Jong, Trauma, war, and violence: Public mental health in socio-cultural context (pp. 93-155). New York City, New York: Springer.

World Bank. (2017). Cambodia: Overview. Retrieved June 28, 2017, from http://www.worldbank.org/en/country/cambodia/overview

Wu, K., Zhang, Y., Liu, Z., Zhou, P., \& Wei, C. (2015). Coexistence and different determinants of posttraumatic stress disorder and posttraumatic growth among Chinese survivors after earthquake: Role of resilience and rumination. Frontiers in Psychology, 6. https://doi.org/10.3389/fpsycg.2015.01043

Yu, Y., Peng, L., Chen, L., Long, L., He, W., Li, M., \& Wang, T. (2014). Resilience and social support promote posttraumatic growth of women with infertility: The mediating role of positive coping. Psychiatry Research, 215, 401-405. https://doi.org/10/1016/j.psychres.2013.10.032

Zoellner, T., \& Maercker, A. (2006). Posttraumatic growth in clinical psychology - A critical review and introduction of a two component model. Clinical Psychology Review, 26, 626-653. https://doi.org/10.1016/j.cpr.2006.01.0

Article history:

Received: 30 July 2020

Revised: 28 August 2020

Accepted: 15 September 2020

\section{For citation:}

Badaracco, J., Sirikantraporn, S., Rich, G.J., Green, J., \& Porter, M.C. (2020). Posttraumatic Growth in Cambodia: A Mixed Methods Study. RUDN Journal of Psychology and Pedagogics, 17(4), 604-623. http://dx.doi.org/10.22363/2313-1683-2020-17-4-604-623

\section{Bio notes:}

Julie Badaracco, Psy.D., graduated with her doctorate in clinical psychology from the California School of Professional Psychology (San Diego), completed her postdoctoral residency - Counseling \& Psychology Services - at the University of California (San Diego). She is currently working towards licensure in California and teaches at the Alliant International University (USA).E-mail: julie.badaracco@gmail.com 
Skultip (Jill) Sirikantraporn, Psy.D., is a founding faculty member at Fulbright University Vietnam (Ho Chi Minh City, Vietnam). In addition to developing the curriculum and teaching, she also serves as a clinical supervisor for the Fulbright Wellness Center. Served as a co-chair of the webinar committee of the American Psychological Association (APA) Division 52 (International Psychology). Her clinical and research interests are in trauma, resilience, and posttraumatic growth from cross-cultural and international perspectives. S. Sirikantraporn is a lead co-editor of an international book Human Strengths and Resilience: Developmental, Cross-Cultural, and International Perspectives (2017). Her recent research focuses on teaching psychology and mental health in Vietnam with her recent published book chapter Teaching Psychology in Vietnam appearing in a book Teaching Psychology around the World, published by Cambridge Scholars Publishing (2020). E-mail: jill.siri@fulbright.edu.vn

Grant J. Rich, Ph.D., LMT BCTMB, Fellow of the American Psychological Association, is Senior Contributing Faculty at Walden University. He received his Ph.D. in Psychology (Human Development) from the University of Chicago. His work focuses on optimal cross-cultural human development and international positive psychology. Dr. Rich is senior editor of six books, including Pathfinders in International Psychology (2015), Internationalizing the Teaching of Psychology (2017), Human Strengths and Resilience: Developmental, Cross-Cultural, and International Perspectives (2018), Teaching Psychology Around the World - Volume 4 (2018) and Volume 5 (2020), Psychology in Southeast Asia: Sociocultural, Clinical and Health Perspectives (2020). His peer reviewed research has appeared in journals including American Psychologist and Journal of Positive Psychology. Dr. Rich has taught at institutions around the globe, recently in Alaska, Cambodia, and India, and lives in Juneau (Alaska, USA). Since 2016, he is member of the Editorial Board of RUDN Journal of Psychology and Pedagogics. Dr. Rich's website may be found at http://rich.socialpsychology.org/. Scopus Author ID: 36841136900. E-mail: optimalex@aol.com

Julii Green, Ph.D. (African American and Eastern Band Cherokee), is Associate Professor in the Clinical Psychology PsyD Department at Alliant International University (USA), has worked in community mental health for over 10 years. She obtained her Ph.D. in clinical psychology from the University of North Dakota and completed postdoctoral studies at University of California, Berkeley (School of Public Health) and University of California, San Francisco (Child Trauma Research Program). She has published in the areas of intimate partner violence (IPV) and friendship variables, the impact of IPV on Native Americans, health disparities among ethnically diverse populations, gender based stereotypes, and the development of tribe focused research. Her training is grounded in behavioral theories and she utilizes cognitive behavioral therapy, feminist and multicultural approaches in practice. Additionally, she established a research lab focused on wellness-based approaches to addressing health disparities among ethnically diverse and marginalized populations. E-mail: jgreen@alliant.edu

Matthew C. Porter, Ph.D., is Associate Professor of Clinical Psychology at the California School of Professional Psychology at Alliant International University (USA). He obtained his doctorate in clinical psychology at the New School for Social Research in 2005, with postdoctoral fellowships at the National Institutes of Health and the Templeton Foundation. He is a past recipient of a Core Fulbright Award for research for work in Brazil. E-mail: mporter@alliant.edu 


\title{
Феномен посттравматического роста в Камбодже: интегративное качественно-количественное исследование
}

\author{
Дж. Бадаракко ${ }^{1}$ С. Сирикантрапорн ${ }^{2}$, Г.Дж. Рич ${ }^{3}$, \\ Д. Грин ${ }^{1}$, М.К. Портер ${ }^{1}$ \\ ${ }^{1}$ Международный университет Аллиант \\ Соединенные Штаты Америки, СА 91803, Алхамбра, S Fremont Ave, 1000, bldg A7 \\ ${ }^{2}$ Университет Фулбрайта во Вьетнаме \\ Социалистическая Республика Вьетнам, Хочимин, р-н 7, \\ Tan Phu Ward, Ton Dat Tien, 105, floor 2, Crescent Plaza \\ ${ }^{3}$ Уолденский университет \\ Соединенные Штать Америки, MN 55401, Миннеаполис, Washington Ave South, 100, suite 900
}

Аннотация. Изучая травмирующие события, большинство исследователей концентрируется на их негативных последствиях, нередко оставляя без внимания то положительное влияние, которое эти события могут оказывать на личность. Ричард Тедески и Лоуренс Калхаун предложили концепцию посттравматического роста (ПТР), основанную на принципах позитивной психологии. ПТР трактуется как процесс личностного роста, наблюдаемый у человека после перенесенной травмы. ПТР может фиксироваться по пяти основным показателям: более полное понимание и принятие жизни, большая интимизация межличностных отношений, укрепление личности, открытие человеком новых возможностей, его духовное развитие. В статье представлены результаты количественного и качественного анализа данных, собранных коллективом авторов в 2015-2016 гг. в Американском университете Пномпеня (Камбоджа). В исследовании, целью которого стало изучение личностного роста в посттравматический период, приняли участие 70 респондентов. Количественный анализ показал внутреннюю согласованность и валидность методики «Диагностика резильентности взрослых» (Adult Resilience Measure) и опросника посттравматического роста (Posttraumatic Growth Inventory) при использовании в камбоджийской выборке. С помощью корреляционного и регрессионного анализа было установлено, что количество пережитых человеком травмирующих событий не влияет на его способность к резильентности и ПТР, при этом выраженность резильентности и ПТР положительно коррелируют между собой. При проведении качественного анализа был использован прием «восхождения к теории», что позволило создать модель ПТР для камбоджийской выборки. Полученная модель включает четыре основных категории переживания ПТР камбоджийцами: личностный рост, развитие межличностных отношений, духовное развитие, связанное с религиозностью, открытие новых возможностей развития. Количественные и качественные результаты исследования свидетельствуют о том, что камбоджийцы в целом переживают посттравматический рост в соответствии с исходной теорией ПТР. В то же время выявляются и некоторые нюансы, имеющие культурную обусловленность, которые необходимо учитывать при изучении ПТР жителей Камбоджи.

Ключевые слова: Камбоджа, культура, кросс-культурный, восхождение к теории, посстравматический рост, резильентность, Юго-Восточная Азия, травма, количественные и качественные методы исследования

\section{История статьи:}

Поступила в редакцию: 30 июля 2020 г.

Принята к печати: 15 сентября 2020 г. 


\section{Для цитирования:}

Badaracco J., Sirikantraporn S., Rich G.J., Green J., Porter M.C. Posttraumatic Growth in Cambodia: A Mixed Methods Study // Вестник Российского университета дружбы народов. Серия: Психология и педагогика. 2020. Т. 17. № 4. С. 604-623. http://dx.doi.org/10.22363/2313-1683-2020-17-4-604-623

\section{Сведения об авторах:}

Бадаракко Джули, Psy.D., закончила Калифорнийскую школу профессиональной психологии в Сан-Диего со степенью доктора клинической психологии, а также постдокторскую ординатуру по специальности «Консультационные и психологические услуги» в Калифорнийском университете в Сан-Диего. В настоящее время преподает в Международном университете Аллиант (США). E-mail: julie.badaracco@gmail.com

Сирикантрапорн Скультип (Джилл), Рsy.D. является членом-основателем Университета Фулбрайта во Вьетнаме (Хошимин, Вьетнам). Помимо преподавания работает клиническим супервизором в оздоровительном центре Фулбрайта. Была сопредседателем Комитета вебинаров Отделения международной психологии Американской психологической ассоциации. Ее клинические и научные интересы связаны с изучением травм, резильентности и посттравматического роста в межкультурном и кросс-культурном контексте. Является ведущим соредактором международной монографии Human Strengths and Resilience: Developmental, Cross-Cultural, and International Perspectives (2017). Результаты ее последних исследований, связанных с преподаванием психологии и курсов по психическому здоровью во Вьетнаме, изложены в главе «Преподавание психологии во Вьетнаме» в монографии Teaching Psychology around the World, опубликованной в 2020 г. издательством Cambridge Scholars Publishing. E-mail: jill.siri@fulbright.edu.vn

Рич Грант Дж., Ph.D., постоянный член Американской психологической ассоциации, заслуженный профессор Уолденского университета. Получил докторскую степень по психологии развития в Чикагском университете. Его научные интересы связаны с изучением оптимального развития человека в кросс-культурном контексте и развитием международной позитивной психологии. Является главным редактором издания Pathfinders in International Psychology (2015) и ведущим соредактором пяти книг, изданных в 2017-2020 гг.: Internationalizing the Teaching of Psychology (2017), Human Strengths and Resilience: Developmental, Cross-Cultural, and International Perspectives (2018), Teaching Psychology Around the World - Volume 4 (2018) и Volume 5 (2020), Psychology in Southeast Asia (2020). Его научные статьи публиковались в ведущих рецензируемых журналах США, включая American Psychologist и Journal of Positive Psychology. Доктор Рич является сертифицированным специалистом по терапевтическому массажу (National Certification Board for Therapeutic Massage and Bodywork, NCBTMB) и редактором научного издания, посвященного количественным исследованиям в сфере массажной терапии - Massage Therapy: The Evidence for Practice (2002). Преподавал в учебных заведениях разных стран мира, в том числе (в последнее время) на Аляске, в Камбодже и Индии. В настоящее время живет в Джуно (Аляска, США). С 2016 года является членом редакционной коллегии журнала «Вестник РУДН. Серия: Психология и педагогика». Персональный сайт: http://rich.socialpsychology.org/. Scopus Author ID: 36841136900. E-mail: optimalex@aol.com

Грин Джули, Ph.D., доцент департамента клинической психологии Международного университета Аллиант (США). Получила степень доктора клинической психологии в Университете Северной Дакоты, проводила исследования в Школе общественного 
здравоохранения Калифорнийского университета в Беркли и в рамках Программы исследования детских травм (UCSF). Публикует научные статьи по проблемам насилия в близких отношениях и факторов дружбы, влияния семейного насилия на коренных американцев, различий в состоянии здоровья среди этнически разнородных популяций, гендерных стереотипов, а также проводит исследования коренных племен. Она придерживается поведенческих теорий, использует на практике когнитивно-поведенческую терапию, феминистские и мультикультурные подходы. Д. Грин создала исследовательскую лабораторию, специализирующуюся на подходах, направленных на оздоровление и устранение различий в состоянии здоровья этнически разнообразных и маргинализированных групп населения. E-mail: jgreen@alliant.edu

Портер Мэтью K., Ph.D., доцент департамента клинической психологии Калифорнийского института профессиональной психологии Международного университета Аллиант (США). Получил докторскую степень по клинической психологии в Новой школе социальных исследований в 2005 г., проводил исследования в Национальном институте здоровья и Фонде Темплтона. Получил грант Фонда Фулбрайта для проведения исследований в Бразилии. E-mail: mporter@alliant.edu 